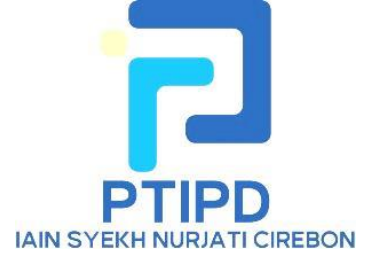

ITEJ Juli-2020, Volume 5 Nomor 1 Page 51 - 65

\section{ITEJ}

Information Technology Engineering Journals eISSN : 2548-2157

Url : https://syekhnurjati.ac.id/journal/index.php/itej

\title{
Decision Making in Internet of Things (IoT) : A Systematic Literature Review
}

\author{
Hespri Yomeldi \\ School of Electrical Engineering and Informatics \\ Institut Teknologi Bandung \\ Bandung, Indonesia \\ heszhost@gmail.com
}

\begin{abstract}
Today's internet technologies support everything that human do. By using integrated technologies the things that connected to internet can provide data. The Internet of Things (IoT) is the new paradigm in provide the data without human communicated. The IoT system support machine to machine communication that can be used to develop smart services that can generate a lot of data. This exponential data can support a decision making. The decision making system depend on availability and reliability of data. This study focus to how the Internet of Thing support decision making system. With a survey of literature to understand the trends, models and factors of decision making in IoT based on previous research. This survey following step by conduct the research question (RQ), then search and observation the previous research from database journal. Based on reviewing 26 articles, this study conclude that the trends of decision making in IoT are implemented on Manufacturing and Industry, Healthcare, Agriculture and Transportation. Besides that the decision model that can support by IoT used Fog Computing, Fuzzy, Game Theoritic, Clustering Based on Multimodal Data Correlation, etc. Meanwhile the decision making factors that influenced by IoT like Latency, data-driven, security, data reliability and accurate. The integrated of model and point of interest on decision making in IoT should be improved. It will be the opportunities and challenge in IoT to support decision making in future.
\end{abstract}

Keywords - Internet of Things, data, decision making, trend, model and factor.

\section{INTRODUCTION}

Internet of Things (IoT) merupakan paradigma baru dalam penyediaan data. IoT dapat menggantikan peran manusia dalam proses pengumpulan data, pengolahan dan diseminasi data dalam bentuk visualisasi. Pada prinsipnya IoT merupakan kumpulan sensor yang yang terkoneksi melalui jaringan internet ataupun intranet yang bisa melakukan komunikasi dengan mesin atau server tanpa melibatkan campur tangan manusia melalui internet protocol (IP) address yang masing-masing dimiliki oleh perangkat atau sistem tersebut[1]. Dengan perkembangan teknologi saat ini, penerapan IoT diberbagai bidang dapat berkembang pesat. Dukungan teknologi komunikasi berupa akses internet yang semakin luas dan tidak terbatas sudah tidak menjadi hambatan lagi. Internet of Things muncul seiring kemudahan komunikasi dan sinkronisasi antar sensor dengan menggunakan jaringan nirkabel (wireless)[2]. 
Penerapan IoT pada saat sekarang ini dapat dijumpai pada bidang industri manufaktur, kesehatan, pertanian dan transportasi[3]. Masing-masing bidang memanfaatkan IoT dengan berbagai penerapan yang pada hakikatnya meningkatkan layanan dan membantu mempermudah dalam pengambilan keputusan. Meskipun IoT dapat diterapkan diberbagai bidang, diperlukan analisis secara komprehensif terhadap kondisi dan aspek-aspek tertentu pada bidang tersebut sehingga implementasi IoT tidak membuat pekerjaan menjadi lebih rumit. Pada makalah ini akan dibahas kondisi dan aspek apa aja yang dapat diterapkan teknologi Internet of Things.

Pada tahapan pengambilan keputusan, data yang dihasilkan oleh perangkat IoT harus diolah menjadi informasi yang berguna. Berbagai macam metode dalam analisis data dapat diterapkan untuk mendukung pengambilan keputusan. Secara hierarki terdapat beberapa proses bagaimana data dapat mendukung pengambilan keputusan yang biasa disebut data analitical. Data analitical menggambarkan bagaimana data kemudian diolah menjadi informasi, kemudian diperoleh suatu pengetahuan, berdasarkan pengetahuan tersebut dibuat suatu kebijakan sehingga diperolah keputusan yang tepat yang membentuk decision support system[6]. Pendekatan kolaboratif dan adaptif untuk mengidentifikasi permasalahan sangat membantu dalam pengelolaan pengambilan keputusan[4].

Beberapa metode yang dapat mendukung dalam pengambilan keputusan pada IoT adalah Cognitif Internet of Things, Game Theoritic, Machine Learning dan Artificial Intelligence. Penerapan metode tergantung pada kebutuhan dan permasalahan. Setiap metode memiliki karakteristik-karakteristik tertentu sehingga memiliki kelebihan dan kekurangan masing-masing. Pada makalah ini juga akan membahas bagaimana penerapan metode decision making pada IoT.

Peran IoT dalam pengambilan keputusan sangat penting, akan tetapi banyak faktor yang dapat mempengaruhi proses pengambilan keputusan yang melibatkan teknologi IoT. Ketepatan dalam pengambilan keputusan merupakan salah satu aspek prioritas untuk mengukur kehandalan teknologi IoT[5]. Oleh karena diperlukan pembahasan terhadap faktor-faktor yang mempengaruhi pengambilan keputusan pada IoT.

Makalah ini terdiri dari 4 bagian, bagian pertama merupakan pengantar, bagian kedua menjelaskan metodologi penelitian dalam makalah ini yaitu dengan menerapkan sistematik literature review, bagian ketiga membahas hasil survei atau review, yaitu bagaimana trend implemtasi decision making dalam IoT, peluang dan tantangan kedepan dan bagian terakhir merupakan kesimpulan penelitian ini.

\section{Metode Penelitian}

\section{A. Sistematic Literature Review}

Sistematic Literature Review(SLR) merupakan salah satu metode dalam melakukan overview penelitian-penelitian sebelumnya yang saling terkait. SLR merupakan salah satu metode standar sehingga proses penelitian selanjutnya dapat dilakukan kembali oleh orang lain dengan hasil yang hampir sama. SLR merupakan penelitian sekunder untuk memetakan, identifikasi, evaluasi, konsolidasi dan mengumpulkan informasi dari hasil studi utama yang terkait dengan topik penelitian[7].

SLR sebagai bagian dari proses survei terhadap topik penelitian berdasarkan keyword yang diinginkan, dengan object surveinya merupakan hasil penelitian yang telah publish di jurnal online. Proses sistematik ini akan menghasilkan gap penelitian yang dapat menjadi peluang dan tantangan untuk penelitian selanjutnya. Pada makalah ini fokus survei terkait decision making pada Internet of Things.

Tujuan utama dari studi literature ini adalah untuk melihat trend dalam implementasi IoT untuk mendukung pengambilan keputusan, model atau metode pengambilan keputusan pada IoT dan faktorfaktor yang mempengaruhi pengambilan keputusan. Untuk memperoleh hasil survei yang komprehensif dilakukan penelitian ini menggunakan hasil riset yang terbit di beberapa jurnal international yang populer seperti IEEE Xplorer, ACM, Springerlink, Sciendirect dan Scopus yang dibatasi dari tahun $2011-2018$.

SLR terdiri dari beberapa tahapan yaitu menentukan pertanyaan penelitian atau Research Question $(R Q)$, kemudian memilih penelitian yang sesuai, melakukan pengumpulan data terkait penelitian sesuai 
makalah yang ditelaah, melakukan analisis dan mendeskripsikan hasil penemuan. Dengan demikian pada prinsipnya SLR bertujuan untuk menjawab RQ terkait topik penelitian dengan cara identifikasi, evaluasi dan analisis hasil riset terdahulu.

\section{B. Research Question}

Penentuan pertanyaan penelitian atau Research Question (RQ) dapat dilakukan dengan melakukan overview awal terkait topik penelitian. Tujuan penentuan RQ adalah untuk menjaga fokus dan arah penelitian, sehingga pengumpulan referensi dan data terkait penelitian bisa teratur dan lebih mudah. Selain itu penting nya analisa awal untuk menentukan RQ adalah mempertajam kata kunci dalam pencarian riset sebelumnya.

Berikut RQ pada penelitian ini, disajikan dalam tabel 1.

Tabel I. Research Question

\begin{tabular}{|c|l|l|}
\hline ID & Research Question & \multicolumn{1}{|c|}{ Motivation } \\
\hline RQ1 & $\begin{array}{l}\text { Apa saja trend } \\
\text { penerapan IoT untuk } \\
\text { mendukung } \\
\text { pengambilan } \\
\text { keputusan? }\end{array}$ & $\begin{array}{l}\text { Identifikasi } \\
\text { penerapan IoT } \\
\text { pada berbagai } \\
\text { bidang yang } \\
\text { mendukung } \\
\text { pengambilan } \\
\text { keputusan }\end{array}$ \\
\hline RQ & $\begin{array}{l}\text { Apa saja model/teknik } \\
\text { yang dapat mendukung } \\
\text { pengambilan } \\
\text { keputusan pada } \\
\text { teknologi IoT ? }\end{array}$ & $\begin{array}{l}\text { Identifikasi } \\
\text { model/teknik yang } \\
\text { terkait data } \\
\text { analitikal yang } \\
\text { mendukung proses } \\
\text { pengambilan } \\
\text { keputusan pada } \\
\text { IoT }\end{array}$ \\
\hline RQ3 & $\begin{array}{l}\text { Apa saja faktor-faktor } \\
\text { atau kriteria yang } \\
\text { mempengaruhi proses } \\
\text { pengambilan } \\
\text { keputusan pada IoT ? }\end{array}$ & $\begin{array}{l}\text { Identifikasi faktor } \\
\text { yang dapat } \\
\text { mempengaruhi } \\
\text { proes pengambilan } \\
\text { keputusan pada } \\
\text { IoT }\end{array}$ \\
\hline
\end{tabular}

\section{Hasil Pencarian}

Proses pencarian makalah pada database jurnal international populer dilakukan dari tanggal 12 Maret sampai 6 April. Makalah yang terkait dengan penelitian diperoleh dengan menggunakan kata kunci ("Decision Making" or "Decision-Making") and ("Internet of Things" or "IoT"). Berikut hasil pencarian yang terkait topic penelitian, disajikan dalam tabel 2. 
Tabel II Hasil Pencarian Terkait Penelitian

\begin{tabular}{|c|l|r|}
\hline Index & Database Jurnal & Jumlah Literatur \\
\hline 1 & IEEE Explorer & 654 \\
\hline 2 & Sciendirect & 384 \\
\hline 3 & Springerlink & 1427 \\
\hline 4 & ACM Digital Library & 43 \\
\hline 5 & Scopus & 585 \\
\hline \multicolumn{2}{|c|}{ Total } & $\mathbf{3 0 9 3}$ \\
\hline
\end{tabular}

Pada tahapan pencarian makalah yang terkait sebagai sumber data dilakukan filterisasi menggunakan inclusion dan exclusion criteria. Kriteria-kriteria ini bertujuan untuk mempermudah penggalian informasi dari makalah yang ditemukan. Adanya pembatasan berdasarkan kriteria khusus, dapat mempertajam proses penelitian. Hal ini juga bertujuan meningkatkan efiesinsi waktu dalam tahapan analisis. Tabel 3 menyajikan inclusion dan exclusion criteria.

Tabel III Inclusion dan Exclusion Criteria.

\begin{tabular}{|c|c|}
\hline \multicolumn{2}{|r|}{ Criteria } \\
\hline $\begin{array}{l}\text { Inclusion } \\
\text { Criteria }\end{array}$ & $\begin{array}{l}\text { - I1 - Makalah penelitian yang } \\
\text { berhubungan dengan trend, model } \\
\text { dan faktor decision making dalam } \\
\text { IoT } \\
\text { - I2 - Makalah berbahasa Inggris } \\
\text { - I3 - Makalah dengan akses Full- } \\
\text { text } \\
\text { - I4 - Makalah publish } 2011-2019\end{array}$ \\
\hline $\begin{array}{l}\text { Exclusion } \\
\text { Criteria }\end{array}$ & $\begin{array}{l}\text { - E1 - Makalah penelitian yang } \\
\text { sama dari database jurnal yang } \\
\text { berbeda } \\
\text { - E1 - Hasil penelitian dalam } \\
\text { bentuk buku, white paper, } \\
\text { publikasi, conference review } \\
\text { - E3 - Makalah yang tidak } \\
\text { berhubungan dengan decision } \\
\text { Making in IoT } \\
\text { E4 - Makalah survei atau } \\
\text { systematic review yang berkaitan } \\
\text { dengan IoT dan Decision Making }\end{array}$ \\
\hline
\end{tabular}




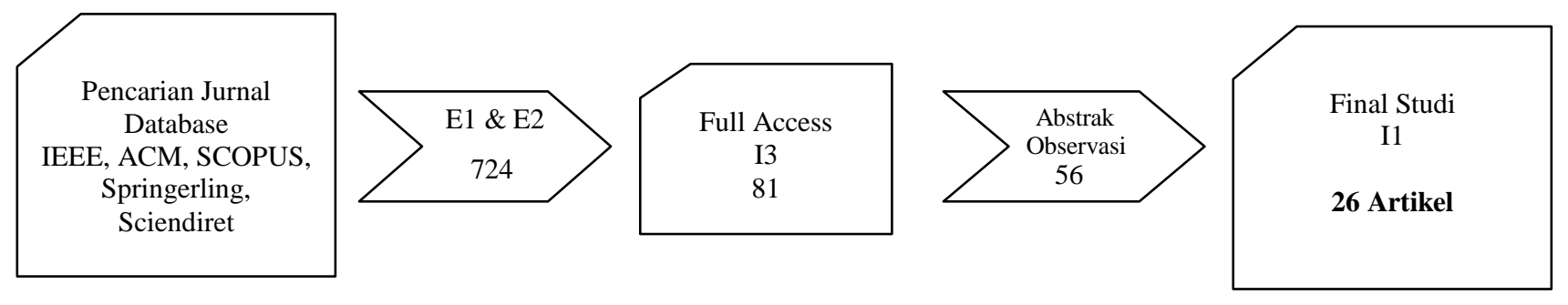

Gambar 1. Proses Pencarian dan Filter dengan Kriteria Khusus

Berdasarkan inklusi dan eklusi kriteria dapat di perolah jumlah makalah yang akan direview. Dari total 3.039 hasil pencarian yang berdasarkan topik yang berkaitan dengan pengambilan keputusan dan Internet of Things, difilter berdasarkan judul dan metadata yang menghasilkan 724 makalah. Kemudian dipilih sebanyak 81 makalah yang full access dan tidak duplikasi. Hasil review abstrak diperoleh 56 makalah terkait, kemudian sebanyak 26 artikel yang direview secara lengkap. Gambar 1 menjelaskan hasil setiap tahapan pencarian dan penyaringan makalah penelitian yang akan dijadikan sumber data dan informasi survei.

Pembatasan makalah yang akan di eksplorasi, dengan menerapkan kriteria khusus (inklusi dan eklusi), bertujuan untuk mendapatkan jumlah informasi yang berkaitan dengan topik penelitian. Hasil pencarian yang masih bersifat sementara dapat ditambahkan kembali apabila setelah penyaringan masih terdapat beberapa sumber yang tidak signifikan berhubungan dengan topik permasalahan dan pertanyaan penelitian.

Pada tahapan terakhir berupa final studi, artikel yang diperoleh sebanyak 26, secara keseluruhan pembahasan dalam setiap makalah ditelaah dan dilakukan analisis. Hasil analisis kemudian di petakan untuk menjawab setiap pertanyaan penelitian.

Pada tahapan sistematik review dapat diberikan filter tambahan untuk meningkatkan hasil studi yaitu berdasarkan indek jurnal yang diterbitkan. Indeks jurnal menunjukan reputasi dari hasil penelitian. Hal ini bertujuan untuk meningkatkan kepuasan dan kepercayaan terhadap penelitaian yang dilakukan. Jurnal yang bereputasi telah melewati review oleh para ahli dibidangnya masing-masing.

Berikut disajikan indeks makalah final studi pada tabel 4.

Tabel III Inclusion dan Exclusion Criteria.

\begin{tabular}{|l|l|c|}
\hline Nomor & Indeks Publikasi & Jumlah Literatur \\
\hline 1 & Periodik Jurnal Q1 & 10 \\
\hline 2 & Periodik Jurnal Q2 & 6 \\
\hline 3 & Periodik Jurnal Q3 & 4 \\
\hline 4 & Periodik Jurnal Q4 & 1 \\
\hline 5 & Proceeding & 5 \\
\hline \multicolumn{2}{r|}{ Total } & $\mathbf{2 6}$ \\
\hline
\end{tabular}




\section{Related Work}

Bagian ini memaparkan beberapa penjelasan dari penelitian Internet of Things untuk mendukung pengambilan keputusan.

Zhang dan Peng[8] membahas bagaimana merancang framework pengambilan keputusan yang diterapkan pada teknologi IoT. Framework dirancang berdasarkan kualitas layanan pada IoT.

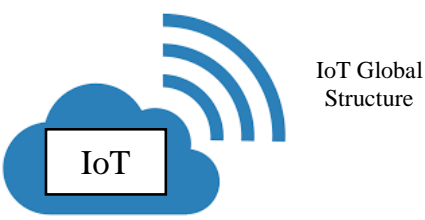

$\sqrt{3}$

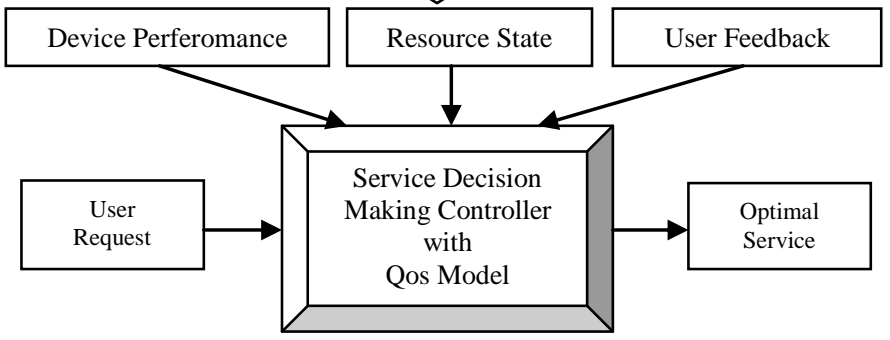

Gambar 2. Decision Making Service Framework (Modified [8])

Penerapan Framework bertujuan untuk mempermudah evaluasi pada pelaksaan pengambilan keputusan yang di dukung oleh teknologi Internet of Things. Keberadaan infrastruktur menjadi pembahasan utama dalam perancangan framework ini.

Chen[9] memaparkan bahwa untuk mengintegrasikan teknologi informasi dan IoT diperlukan sebuah intelligent integrated service platform. Platform ini dirancang untuk menghasilkan informasi secara langsung berdasarkan data yang dikumpulkan oleh sensor IoT. Platform ini memungkina pengambilan keputusan secara langsung dan lebih mudah. Penerapan platform ini mampu mengatasi permasalahan waktu dalam pengambilan keputusan, selain itu kendala jumlah data yang banyak dapat teratasi.

Wu,dkk[10] memberikan hasil penelitian bahwa diperlukan teknologi Cognitif Internet of Things (CIoT) yang menerapkan cara berpikir manusia.teknologi ini merupakan paradigm baru untuk memberikan suatu objek kemampuan untuk learn, think dan understanding. Rancangan teknologi CIoT dapat meningkatkan performa perangkat atau device IoT sehingga meningkatkan keakuratan pengambilan keputusan.

\section{HASIL PENELITIAN}

Internet of Things dengan penerapan jaringan yang sangat heterogen dengan berbagai jenis objek[11] memberikan peluang dan tantangan dalam proses pengambilan keputusan. Segala sesuatu yang terkoneksi dengan internet dapat memberikan data yang tak terhingga sehinggga dapat dimanfaatkan untuk memperoleh informasi tertentu. Kemudahan akses menjadi perbedaan sehingga dengan beragam perangkat yang terhubung dengan objek, data yang dihasilkan tetap dapat digunakan. Dengan jumlah objek yang sangat bervariasi diperlukan sistem pengelolaan perangkat dan aktifitasnya sehingga sistem IoT dapat berjalan dengan efisien[12]. Service-oriented Workflows Management (WfMS) merupakan salah satu alat yang dapat digunakan dalam pengelolaan sistem IoT yang dapat mendukung proses pengambilan Keputusan[12]. 
Pada prinsip teknologi IoT merupakan multi-agen sistem yang memfasilitasi interaksi antara mesin tanpa campur tangan manusia[13]. Multi-agen menghubungkan antara objek, lingkungan observasi dan sistem untuk menghasilkan data dan informasi yang dapat mendukung pengambilan keputusan.

Dukungan teknologi dalam pengembangan IoT semakin mempermudah penerapannya dalam meningkatkan kualitas layanan. Pendekatan kualitas layanan dalam pengembangan IoT[8], menjadikan efektifitas dan efisiensi semaking tinggi, hal ini dikarenakan orientasi IoT yang dikembangkan disesuikan dengan area pengembangan sehingga kebutuhan sistem menyesuaikan area IoT.

\section{A. Tren Utama Penerapan IoT untuk Decision Making}

Tren utama dalam penerapan IoT yang mendukung pengambilan keputusan dapat dilihat dari tabel 4.

Tabel IV Tren Utama IoT untuk Decision Making.

\begin{tabular}{|r|l|r|}
\hline No & IoT Environmet & \multicolumn{1}{c|}{ Jumlah Literatur } \\
\hline 1 & Kesehatan & {$[6][12][15][18][19][20]$} \\
\hline 2 & Pertanian & {$[5][14]$} \\
\hline 3 & Transportation & {$[9][13][20][21][23][20][26]$} \\
\hline 4 & $\begin{array}{l}\text { Manufacturing dan } \\
\text { Industri }\end{array}$ & {$[2][8][19]$} \\
\hline 5 & Smart Home & \\
\hline
\end{tabular}

Dari tabel diatas dapat diperoleh informasi bahwa penerapan IoT untuk mendukung pengambilan keputusan dapat diterapkan di berbagai bidang. Berdasarkan hasil penelitian bidang kesehatan paling banyak menerapkan teknologi IoT, kemudian diikuti sektor manufaktur dan industri. Sektor pertanian menjadi domain yang menarik untuk implementasi IoT. Sementara transportasi dan smarthome menjadi komponen penting dalam pengembangan smart city, dimana beragam teknologi diintegrasikan termasuk IoT untuk meningkatkan pelayanan terhadap individu atau pemerintah.

Penerapan IoT pada bidang kesehatan sebagain besar terfokus pada kesehatan personal, bertujuan untuk membantu pengambilan keputusan. Identikasi secara realtime kondisi kesehatan individu, update laporan. IoT juga dapat memberikan prediksi penyakit[6], pada pasien seperti cancer, dll.

Pada bidang pertanian IoT berperan dalam mengidentifikasi kualitas tanaman dan lahan untuk meningkatkan produktifitas hasil pertanian[5]. Sensor IoT dapat memetakan biogeografi terhadap faktor-faktor lingkungan yang mendukung lingkungan pertanian[14].

Bidang Manufaktur dan Industri menerapkan IoT untuk kontrol peralatan dan suplai logistik[13]. Sektor industri dan manufaktur memanfaatkan IoT untuk pengambilan keputusan pada rantai produksi[23]. Industri dan manufaktor melakukan integrasi IoT untuk pada sistem control produksi untuk memudahkan pengambilan keputusan terkait produksi dan tenaga kerja.

Dukungan IoT pada smartcity dapat terlihat pada bidang transportasi dan smarthome. Idealnya pendekatan IoT untuk mempermudah aktifitas masyarakat. Permasalahan transportasi dapat diminimalisir dengen penerapan IoT diantaranya untuk pengelolaan parker dan deteksi kendaraan jumlah kendaraan.[26]. Pengaturan untuk lampu lalu lintas di perkotaan dapat menerapkan IoT[17], adanya sistem ini dapat mengurangi tingkat kemacetan. Komponen smartcity yang penting yaitu smarthome. Teknologi smarthome telah melukan transformasi dengan pendekatan teknologi IoT. Salah satu penerapannya yaitu identifikasi objek visual yang dapat diterapkan pada lingkungan rumah[19]. 


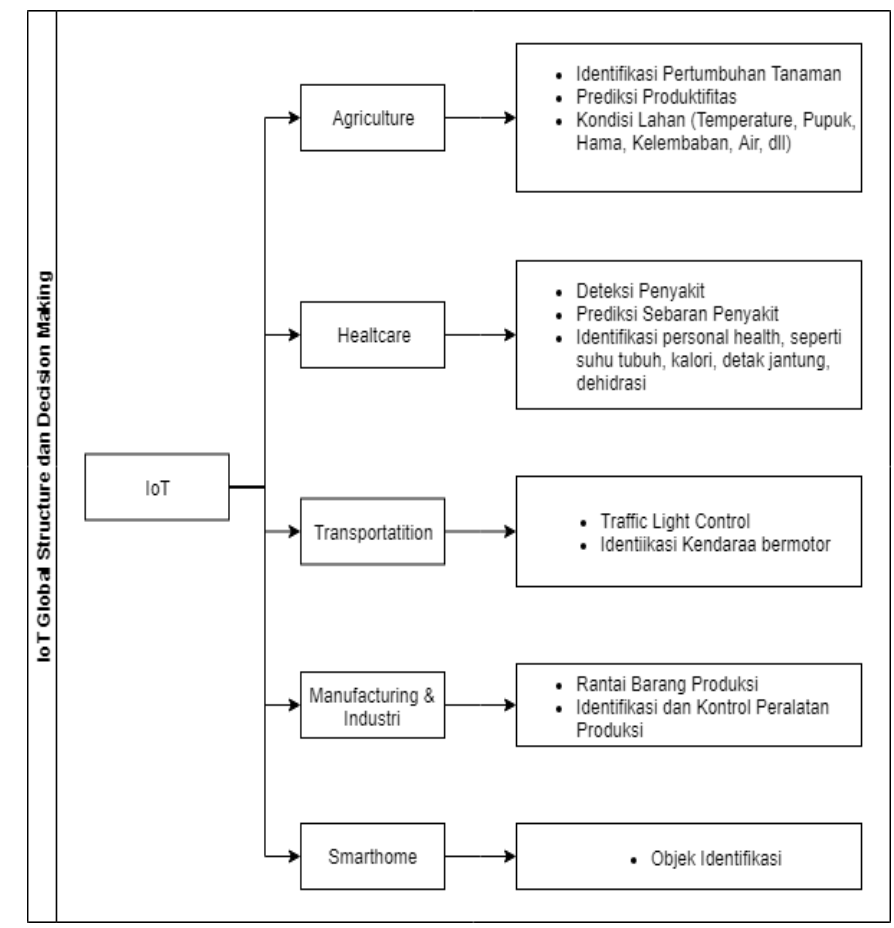

Gambar 3. Mapping IoT Global Environtment Terhadap Motivasi Pengambilan Keputusan

Berdasarkan gambar 3 diatas IoT sangat mendukung pengambilan keputusan diberbagai bidang. Implementasi IoT diberbagai bidang bertujuan untuk mempermudah dalam pengambilan data dan informasi. Data dan informasi berperan penting dalam proses pengambilan keputusan.

\section{B. Model Decision Making pada IoT}

Sistem IoT terdiri perangkat sensor yang mampu mengcapture data. Data tersebut ada yang tersimpan dalam sensor ada yang langsung terkoneksi dengan internet untuk di kirim ke server. Data yang dikumpulkan digunkan untuk pengambilan keputusan setelah diolah menjadi informasi.

Dukungan teknologi memungkin IoT dapat melakukan analisa data secara mandiri dan manyajikan informasi secara akurat. Proses penyajian informasi ini membutuhkan metode analitik yang mendukung pengambilan keputusan. Beberapa motede ini akan membentuk suatu model pengambilan keputusan yang dapat diterapkan pada Internet of Things.

Berikut model decision making pada IoT disajikan pada table 5. 
Tabel V Model Decision Making pada IoT

\begin{tabular}{|c|l|c|}
\hline No & $\begin{array}{l}\text { Model Decision } \\
\text { Making }\end{array}$ & Jumlah Literatur \\
\hline 1 & $\begin{array}{l}\text { Intelligent } \\
\text { Decision } \\
\text { Making }\end{array}$ & {$[4][8][10][13][16][20][24]$} \\
\hline 2 & $\begin{array}{l}\text { Fuzzy Decision } \\
\text { Making }\end{array}$ & {$[9][14][23]$} \\
\hline 3 & $\begin{array}{l}\text { Proaktif } \\
\text { Decision } \\
\text { Making }\end{array}$ & $\begin{array}{l}\text { Real-time } \\
\text { Decision } \\
\text { Making }\end{array}$ \\
\hline 5 & $\begin{array}{l}\text { Markov } \\
\text { Decision } \\
\text { Making }\end{array}$ & {$[1][17][18][19][25]$} \\
\hline
\end{tabular}

Intelligent Decision Making adalah model atau teknik pengambilan keputusan dimana sistem mampu mentransformasikan konten data menjadi informasi yang bermakna, mengklasifikasikan dan menerapkannya[8]. Model ini memberikan analisis terhadap pada pada IoT sehingga tahapan pengambilan keputusan menjadi lebih cepat dan tepat. Model pengambilan keputusan seperti banyak diterapkan dalam IoT karena beriorentasi pada analisis data secara mandiri. Modelnya juga tepat diterapkan dengan data berskala besar.

Fuzzy Decision Making merupakan model yang pioneer dalam pengambilan keputusan dengan variasi data yang besar. Teori fuzzy mengedepankan ketidakpastian dan ketidakjelasan variabelvariabel informasi[23]. Metode fuzzy sangat cocok diterapkan pada optimalisasi pengambilan keputusan dengan varibel berpengaruh yang cukup besar. Salah satu penerapan nya yaitu pada optimalisasi strategi rantai barang.

Proaktif Decision Making menjadi tren masa kini dan masa depan yang merupakan pengambangan tingkat lanjut dari Intelligent Decision Making. Model pengambilan keputusan ini melakukan analisas data, kemudian melakuan prediksi dari data analisis. Hasil prediksi dan analisis menjadi report yang akan membantu pengambilan keputusan, setiap hasil prediksi dan analisis dilaporkan secara langsung melalui notifikasi dengan akses internet[5]. Metode ini menggunakan prinsip " Detect- PredictDecide-Act". Untuk saat sekarang ini prinsip "Act" atau aksi berupa notifikasi sangat bermanfaat dan memungkinan dengan dukungan akses internet yang sangat luas. Model seperti ini sangat cocok diterapkan untuk melakukan pencegahan dini, atau sebagai early warning system pada berbagai bidang.

Real-time Decision Making telah diterapka pada IoT untuk memperoleh informasi terkini. Model ini menghasilkan output visualisasi dan management data, informasi, pengetahuan dan keputusan[1]. Penyajian data dan informasi dari sensor dapat diperoleh secara cepat dan bahkan langsung, seperti pada personal health care sensor. Prinsip pada model ini adalah "sensing, processing, reacting, learning"[1]. Tahapan pengambilan keputusan yaitu pada proses "reacting". Model ini menerapkan "Artificial Intelligent" pada tahapan "learning". Penerapan real-time Decision Making salah satunya menggunakan Game Theoritic Algorithm pada kontrol lampu lalulintas.[17].

Markov Decision Making memiliki kesamaan dengan fuzzy, model ini diterapkan dengan random dan dinamis variabel[11], yang memiliki korelasi terhadap informasi yang dicari. Model ini juga dapat diterapkan untuk dengan variabel analisis yang dapat berubah tetapi significant mempengaruhi hasil. 
Sensor IoT dapat menyediakan data yang fleksibel secara simultan. Model ini sangat cocok pada penerapan IoT dengan environment luas dengan objek pengamatan yang banyak dan bervariasi. Salah satu penerapannya yaitu peningkatan deep learning resource IoT[3].

Dari berbagai model pengambilan keputusan yang dapat diterapkan pada IoT, proses data analitik menjadi bagian penting. Sementara itu penyajian data dan informasi secara realtime merupakan persyaratan utama untuk meningkatkan kualitas layanan IoT.

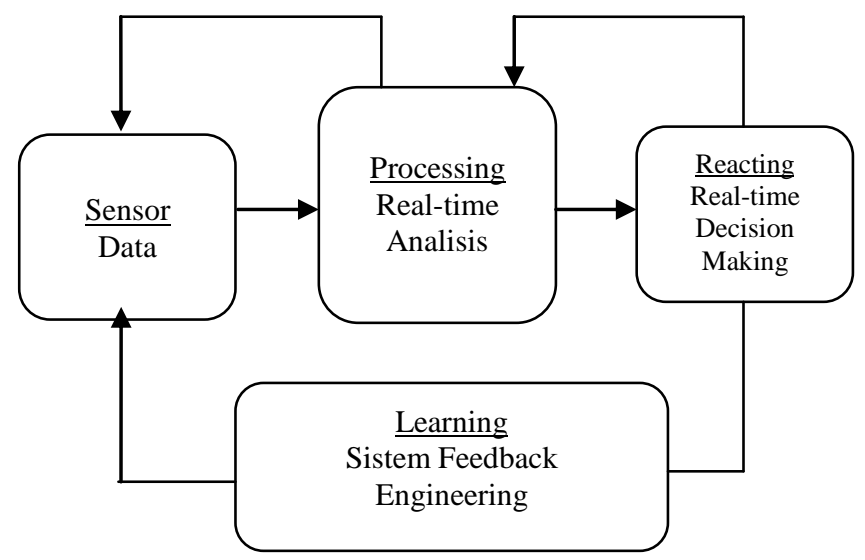

Gambar 3. Real-time decision informatics [1]

Gambar 3 menjelaskan penentuan pengambilan keputusan berdasarkan perspektif engineering. Sebuah data yang diterima sensor, dikumpulkan, digabungkan (homogen dan heterogen), dilakukan pengolahan dan analisis untuk memperoleh informasi yang diperlukan, kemudian reaksi diperlukan untuk mempengaruhi keputusan yang diinformasikan (pengambilan keputusan), berdasarkan keputusan yang diambil diperoleh pengetahuan yang digunakan untuk dipelajari, sehingga dapat menghasilkan ke] Tabel VI. Klasifikasi Model Decisioan Making (DM) pada IoT dan Informasi Terkait

\begin{tabular}{|c|c|c|c|}
\hline Model DM & Methode/Alghoritm & Kelebihan & New Finding \\
\hline \multirow[t]{5}{*}{ Intelligent Decision Making } & & $\begin{array}{l}\text { - Adaptif case management } \\
\text { - kolaborasi }\end{array}$ & - Arsitektur DM - SOA \\
\hline & - Analytical Hierarchy Process [8] & $\begin{array}{l}\text { - Evaluasi hasil } \\
\text { - OoS Model }\end{array}$ & - Framework DM - QoS \\
\hline & - Cognitive internet of things [10] & & $\begin{array}{l}\text { - Knowledge assisted } \\
\text { learning }\end{array}$ \\
\hline & $\begin{array}{l}\text { - Intelligent } \quad \text { Multi-agent } \\
\text { (Artificial Intellignence) [13] }\end{array}$ & $\begin{array}{l}\text { - High-level intelligent } \\
\text { - Semantic analize } \\
\text { - Distributed envi } \\
\text { - Heterogeneous envi }\end{array}$ & $\begin{array}{l}\text { - Distributed reputation } \\
\text { model }\end{array}$ \\
\hline & $\begin{array}{l}\text { - Device Clustering Algorithm [20] } \\
\text { - Distributed Consensus Algorithm [16] }\end{array}$ & $\begin{array}{l}\text { - Data transmission } \\
\text { improve }\end{array}$ & $\begin{array}{l}\text { - Korelasi multimodal d: } \\
\text { dan device } \\
\text { - Service-oriented IoT }\end{array}$ \\
\hline Fuzzy Decision Making & - Fuzzy cognitive maps (FCM) [9] & $\begin{array}{l}\text { - Minimize multi } \\
\text { parameter IoT }\end{array}$ & $\begin{array}{l}\text { - Critical factor bisnis } \\
\text { operasi pada IoT }\end{array}$ \\
\hline Proactive Decision Making & - Arima Prediction Model [5] & $\begin{array}{l}\text { - Multiple maps,loops, } \\
\text { cycle }\end{array}$ & $\begin{array}{l}\text { - Framework Proaktive } \\
\text { with Notifikasi }\end{array}$ \\
\hline Real-time Decision Making & $\begin{array}{l}\text { - Computational Offloading Algorihtm } \\
\text { [19] } \\
\text { - Game Theroritic[17] }\end{array}$ & - Prediktif analisis & $\begin{array}{l}\text { - Visual IoT-based } \\
\text { - Low -latency } \\
\text { - Smart traffic light with }\end{array}$ \\
\hline & & $\begin{array}{l}\text { - Visual data processing } \\
\text { - Image processing }\end{array}$ & priority \& non priority \\
\hline Markov Decision Making & - Markov Decision Proces [11] & $\begin{array}{l}\text { - Apply different model } \\
\text { - Realtime }\end{array}$ & $\begin{array}{l}\text { - Adaptif security } \\
\text { framework on IoT }\end{array}$ \\
\hline
\end{tabular}




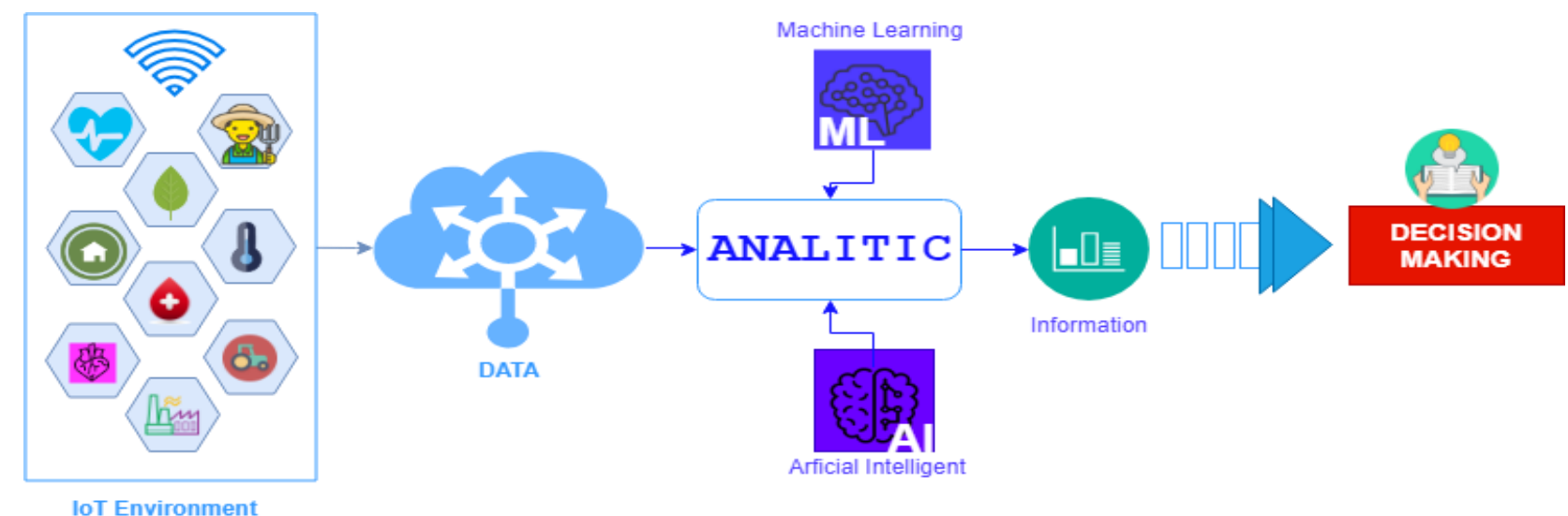

Gambar 4. Framework Decision Making in IoT

Tabel 6 menunjukan klasifikasi model pengambilan keputusan pada IoT berdasarkan algoritma dan metode yang digunakan. Pada tabel dapat terlihat bahwa pendekatan kasus dan kebutuhan informasi menjadi dasar utama dalam pemilihan algoritma. Pada tabel diatas terlihat dengan jelas beberapa kelebihan dari setiap metode yang digunakan. Implementasi metode menghasilkan temuan baru pada proses pengambilan keputusan dengan teknologi IoT. Temuan-temuan terbaru ini merupakan peluang untuk diterapkan pada masa mendatang dengan meningkatkan atau menggabungkan beberapa temuan. Tujuan utama dari penelitian diatas adalah bagaimana meningkatkan peran IoT dalam mendukung proses pengambilan keputusan.

Gambar 5 merupakan desain framework Decision Making in IoT berdasarkan hasil identifikasi dan analisis model decision making yang diterapkan pada beberapa IoT environment. Pada framework diatas ditekankan proses data analitical dapat di bagi menjadi 2 bagian yaitu menggunakan Machine Learning ataupun Artificail Intelligence. Peneparan 2 metode diatas diharapkan mampu meningkat kualitas informasi yang dihasilkan sehingga keputusan yang diambil lebih tepat dan sesuai kebutuhan. Dengan adanya proses data analitical sistem IoT kedepannya dapat memberikan melakukan pengambilan keputusan secara otomatis yang berasal dari pembelajaran terhadap informasi-informasi yang telah diolah menjadi pengetahuan.

\section{Faktor yang mempengaruhi Decision Making pada IoT}

Untuk mendapatkan keputusan yang tepat dari suatu informasi, harus dipastikan bahwa informasi yang diterima valid dan benar. Dengan beragamnya data yang dihasilkan dengan jumlah sensor yang banyak pada sistem IoT[11], banyak faktor yang dapat mempengaruhi proses pengambilan keputusan. Faktor-faktor yang mempengaruhi pengambilan keputusan pada IoT dapat berasal dari IoT environment, device dan sistem IoT sendiri. 
Berikut faktor-faktor yang mempengaruhi pengembilan keputusan pada IoT, disajikan pada table 7.

Tabel VI. Faktor -faktor yang Mempengaruhi DM-IoT

\begin{tabular}{|l|l|l|}
\hline Index & \multicolumn{1}{|c|}{ Faktor } & \multicolumn{1}{c|}{ Deskripsi } \\
\hline L & Latency & $\begin{array}{l}\text { Merupakan waktu yang } \\
\text { diperlukan unuk } \\
\text { transmisi/pengiriman } \\
\text { data/informasi }\end{array}$ \\
\hline DD & Data-driven & $\begin{array}{l}\text { Merupakan pengambilan } \\
\text { data pada device atau } \\
\text { perangkat IoT }\end{array}$ \\
\hline S & Security & $\begin{array}{l}\text { Tingkatkan keamanan } \\
\text { kepercayaan terhadap data } \\
\text { pada IoT }\end{array}$ \\
\hline RA & $\begin{array}{l}\text { Reliabity dan } \\
\text { Accurate }\end{array}$ & $\begin{array}{l}\text { Tingkat keberlangsungan } \\
\text { data yang kontinious dan } \\
\text { keakuratan data }\end{array}$ \\
\hline
\end{tabular}

Faktor-faktor diatas merupakan faktor yang berpengaruh signifikan pada proses pengambilan keputusan yang menerapkan teknologi IoT. Significant mempengaruhi keputusan yang dihasilkan dan memeliki peluang jika dibiarkan akan diperoleh keputusan yang salah.

Tabel VII. Main-Context Faktor-Faktor pada DM - IoT

\begin{tabular}{|l|l|c|}
\hline Factor & \multicolumn{1}{|c|}{ Main Context } & \multicolumn{1}{c|}{ Literature } \\
\hline L & $\begin{array}{l}\bullet \text { Time Lack } \\
\bullet \text { Real-time }\end{array}$ & {$[1][5][6][13][17][18][19][22][25]$} \\
\hline DD & $\begin{array}{l}\bullet \text { Scalable/Large } \\
\bullet \text { Heterogen }\end{array}$ & {$[2][12][13][14][16][20][21][24]$} \\
\hline S & $\begin{array}{l}\bullet \text { Security } \\
\bullet \text { Missing Value }\end{array}$ & {$[3][11][23]$} \\
\hline RA & $\begin{array}{l}\bullet \text { Suistanable } \\
\bullet \text { Data Analitic }\end{array}$ & {$[5][6][9][10][16][23][26]$} \\
\hline
\end{tabular}

Beberapa konteks utama yang mempengaruhi pengambilan keputusan pada IoT yaitu faktor Latency yang memiliki time lack terhadapa transmisi data dan real-time informasi. Kedua hal ini berperan signifikan pada pengambilan keputusan. Permasalahan waktu merupakan komponen penting dalam decision making[26]. Yang kedua adalah Data-driven faktor yang terdiri dari jumlah data yang besar (scalable) dan keheterogen data dan objek obsevasi. Data dengan skala besar dibutuhkan metode khusus agar pengiriman data dapat diproses lebih cepat. Penerapan algoritma sangat penting untuk mengatasi masalah ini[21]. 
Selanjutnya terdapat faktor security yang terdiri security dan missing value pada data. Keamanan data yang dihasilkan sangat penting untuk menghasilkan keputusan yang tepat sama halnya dengan missing value yang sangat mungkin terjadi dengan jumlah sensor yang cukup banyak pada teknologi IoT sangat rentan dengan kehilangan data[3][11].

Faktor selanjunya adalah reliabiliti dan akurasi, dua hal ini sangat dominan pada teknologi IoT, fungsi utama sensor adalah menyediakan data secara terus menerus baik real-time maupun periodik. Keberlangsungan penyediaan data memiliki peran vital pada pengambilan keputusan IoT[10]. Proses data analitik juga menjadi komponen penting untuk menghasilkan informasi yang akurat, penerapan berbagai algoritma mampu mempermudah proses analisis, sehingga menghasil keputusan yang tepat[23][26].

Beberapa teknologi dapat digunakan untuk mengatasi permasalahan yang muncul karena faktorfaktor yang mempengaruhi pengambilan keputusan pada IoT. Berikut teknologi yang dapat digunakan.

The Cloud Computing adalah teknologi layanan yang tersedia di Internet dengan hardware dan software yang terpusat untuk memberikan layanan tersebut[15]. Teknologi ini mampu mengatasi permasalahan penyajian data secara realtime dan pengolahan data dalam skala besar. Teknologi cloud computing saat ini dikembang pada mobile cloud computing.

The Fog Computing Paradigm merupakan teknologi yang muncul untuk memfasilitasi IoT, teknologi ini bertujuan memfasilitasi layanan cloud terhadap komponen "things" pada IoT yaitu sensor, embed sistem dan smartphone dan kendaraan bermotor[15]. Teknologi ini mampu mengurangi latency transmisi data pada perangkat IoT sehingga mampu menyajikan informasi lebih cepat.

The Edge Computing merupakan teknologi untuk pengiriman data yang beragam dengan skala besar dengan penerapan per unit waktu dari aplikasi atau sensor yang berbeda[3]. Edge Computing mampu menyediakan analisis data secara real-time, rendah biaya operational, data skalabilitas tinggi, mengurangi latensi dan meningkatkan kualitas layanan[22]. Pengembangan kedepan teknologi ini adalah mobile edge computing.

Mobile Edge Computing dapat diterapkan pada visual based-IoT untuk mengurangi latency data visual. Penerapan ini menggunakan pendekatan offloading computational[19].

Dari beberapa teknologi diatas secara umum penerapannya bertujuan untuk mengatasi permasalahan data heteregen dalam skala besar yang mempengaruhi latency pada pengumpulan dan transmisi, dan proses data-driven. Sementara itu untuk akurasi analisis data dan permasalahan[27] keamanan data diperlukan penerapan Artificial Inteligent dan Machine Learning, baik untuk optimalisasi fungsi device dan server maupun dalam analitical data. Dengan demikian diperlukan integrasi teknologi sehingga IoT sistem dapat mendukung proses pengambilan keputusan.

\section{KESIMPULAN}

Pada penelitian diidentifikasi, evaluasi dan analisis pengambilan keputusan pada Internet of Things. Penelitian ini menggunakan metode sistematik literature review dengan melakukan pencarian pada beberapa database jurnal populer.

Berdasarkan hasil review diperoleh kesimpulan bahwa trend utama penerapan IoT untuk mendukung pengambilan keputusan yaitu pada sektor kesehatan, manufaktur dan industri, transportasi, pertanian dan smarthome. Sektor kesehatan merupakan yang paling banyak penerapannya, terutama terkait personal healthcare.

Sementara itu model Decision Making yang diterapkan pada IoT cukup beragam yaitu Intelligent Decision Making ,Fuzzy Decision Making, Proactive Decision Making, Real-time Decision Making, Markov Decision Making. Penerapan model paling banyak yaitu Intelligent Decision Making, sementara model yang berkembang saat ini adalah Proactive dan Real-time Decision Making yang merupakan pengembanga tingkat lanjut dari intelligent decision making model. 
Faktor-faktor yang mempengaruhi pengambilan keputusan pada IoT yaitu Latency, Data-driven, Security Reliabity dan Akuracy . Faktor-faktor ini cukup significant dalam mempengaruhi keputusan yang diambil pada IoT.

Untuk mengatasi permasalah yang muncul dari faktor-faktor yang berpengaruh diatas dapat diterapkan teknologi distributed computing (cloud, edge, fog) yang diintegrasikan dengan penerapan Artificial Intelligent dan Machine Learning untuk proses analitikal data maupun optimalisasi device IoT.

Dengan demikian penggambaran trend,model dan faktor-faktor yang mempengaruhi pengambilan keputusan pada IoT diatas dapat memberikan peluang dan tantangan baru dalam pengembangan Decision Making pada Internet of Things kedepannya.

\section{REFERENCES}

[1] J. M. Tien, "Internet of Things, Real-Time Decision Making, and Artificial Intelligence," Ann. Data Sci., vol. 4, no. 2, pp. 149-178, 2017.

[2] T. R. Bennett, N. Gans, and R. Jafari, "Data-Driven Synchronization for Internet-of-Things Systems," ACM Trans. Embed. Comput. Syst., vol. 16, no. 3, pp. 1-24, 2017.

[3] Y. Wei, F. R. Yu, M. Song, and Z. Han, "Joint Optimization of Caching, Computing, and Radio Resources for Fog-Enabled loT Using Natural Actor-Critic Deep Reinforcement Learning," IEEE Internet Things J., vol. PP, no. c, p. 1, 2018.

[4] A. Zimmermann et al., "Intelligent Decision Technologies 2016," vol. 57, pp. 27-37, 2016.

[5] U. J. L. dos Santos, G. Pessin, C. A. da Costa, and R. da Rosa Righi, "AgriPrediction: A proactive internet of things model to anticipate problems and improve production in agricultural crops," Comput. Electron. Agric., no. November 2017, pp. 1-12, 2018.

[6] A. Masood et al., "Computer-Assisted Decision Support System in Pulmonary Cancer detection and stage classification on CT images," J. Biomed. Inform., vol. 79, no. January, pp. 117-128, 2018.

[7] A. Dresch, D. P. Lacerda, and J. A. V. Antunes, Design science research: A method for science and technology advancement. 2015.

[8] Q. Zhang and D. W. Peng, "Intelligent decision-making service framework based on QoS model in the internet of things," Proc. - 11th Int. Symp. Distrib. Comput. Appl. to Business, Eng. Sci. DCABES 2012, pp. 103-107, 2012.

[9] R. Y. Chen, "Intelligent service-integrated platform based on IOT technology using FCM and FQFD method," 2013 IEEE 6th Int. Conf. Adv. Infocomm Technol. ICAIT 2013, no. i, pp. 151-152, 2013.

[10] Q. Wu et al., "Cognitive internet of things: A new paradigm beyond connection," IEEE Internet Things J., vol. 1, no. 2, pp. 129-143, 2014.

[11] T. Friedrich, J. He, T. Jansen, and A. Moraglio, "MDPAS: Markov Decision Process Based Adaptive Security for Sensors in Internet of Things," Theor. Comput. Sci., vol. 561, no. PA, pp. $1-2,2015$.

[12] J. Mass, C. Chang, and S. N. Srirama, "Context-aware edge process management for mobile thing-to-fog environment," pp. 1-7, 2018

[13] K. Kravari, M. Ustyantseva, and N. Bassiliades, "Drama: An iot-enabled distributed reputation agent model," ACM Int. Conf. Proceeding Ser., 2018.

[14] A. Paraskevopoulos, P. I. Dallas, K. Siakavara, and S. K. Goudos, "Cognitive Radio Engine Design for IoT Using Real-Coded Biogeography-Based Optimization and Fuzzy Decision Making," Wirel. Pers. Commun., vol. 97, no. 2, pp. 1813-1833, 2017. 
[15] P. J. Escamilla-Ambrosio, A. Rodríguez-Mota, E. Aguirre-Anaya, R. Acosta-Bermejo, and M. Salinas-Rosales, "Distributing computing in the internet of things: Cloud, fog and edge computing overview," Stud. Comput. Intell., vol. 731, pp. 87-115, 2018.

[16] S. Li, G. Oikonomou, T. Tryfonas, T. M. Chen, and L. Da Xu, "A distributed consensus algorithm for decision making in service-oriented internet of things," IEEE Trans. Ind. Informatics, vol. 10, no. 2, pp. 1461-1468, 2014.

[17] K. H. N. Bui, J. E. Jung, and D. Camacho, "Game theoretic approach on Real-time decision making for IoT-based traffic light control," Concurr. Comput., vol. 29, no. 11, 2017.

[18] M. M. Rathore, A. Ahmad, A. Paul, J1. Wan, and D. Zhang, "Real-time Medical Emergency Response System: Exploiting IoT and Big Data for Public Health," J. Med. Syst., vol. 40, no. 12, 2016.

[19] H. Trinh et al., "Energy-Aware Mobile Edge Computing and Routing for Low-Latency Visual Data Processing," IEEE Trans. Multimed., vol. 20, no. 10, pp. 2562-2577, 2018.

[20] K. Lin, D. Wang, F. Xia, and H. Ge, "Device Clustering Algorithm Based on Multimodal Data Correlation in Cognitive Internet of Things," IEEE Internet Things J., vol. 5, no. 4, pp. 22632271, 2018.

[21] A. Bader, H. Ghazzai, A. Kadri, and M. S. Alouini, "Front-end intelligence for large-scale application-oriented internet-of-things," IEEE Access, vol. 4, pp. 3257-3272, 2016.

[22] H. El-Sayed et al., "Edge of Things: The Big Picture on the Integration of Edge, IoT and the Cloud in a Distributed Computing Environment," IEEE Access, vol. 6, pp. 1706-1717, 2017.

[23] X. Yue and Y. Chen, "Strategy Optimization of Supply Chain Enterprises Based on Fuzzy Decision Making Model in Internet of Things," IEEE Access, vol. 6, pp. 70378-70387, 2018.

[24] B. Balis et al., "Holistic approach to management of IT infrastructure for environmental monitoring and decision support systems with urgent computing capabilities," Futur. Gener. Comput. Syst., vol. 79, pp. 128-143, 2018.

[25] A. Taherkordi, F. Eliassen, M. Mcdonald, and G. Horn, "Context-Driven and Real-Time Provisioning of Data-Centric IoT Services in the Cloud," ACM Trans. Internet Technol., vol. 19, no. 1, pp. 1-24, 2018.

[26] J. Danner, L. Wills, E. M. Ruiz, and L. W. Lerner, "Rapid Precedent-Aware Pedestrian and Car Classification on Constrained IoT Platforms," pp. 29-36, 2016.

[27] Y. Marine and S. Saluky, "Penerapan IoT untuk Kota Cerdas", itej, vol. 3, no. 1, pp. 36 - 47, Jul. 2018. 